GHOST PROTOCOL 


$\begin{array}{cccc}G & H & O & S \\ O & C & O & L \\ T & P & R & O \\ L & G & H & C \\ O & T & O & C \\ O & S & T & P \\ C & \bigcirc & L & G\end{array}$




\title{
GHOST PROTOCOL
}

\author{
DEVELOPMENT AND DISPLACEMENT
}

IN GLOBAL CHINA

Carlos Rojas and Ralph A. Litzinger, editors 
(C) 2016 Duke University Press

All rights reserved

Printed in the United States of America on acid-free paper $\infty$

Designed by Amy Ruth Buchanan

Typeset in Minion and Avenir by

Westchester Publishing Services

Library of Congress Cataloging-in-Publication Data

Names: Rojas, Carlos, [date] editor. | Litzinger, Ralph A., [date] editor.

Title: Ghost protocol : development and displacement in global

China / Carlos Rojas and Ralph A. Litzinger, editors.

Description: Durham : Duke University Press, 2016. | Includes bibliographical references and index.

Identifiers: LCCN 2016004716 (print)

LCCN 2016006130 (ebook)

ISBN 9780822361770 (hardcover : alk. paper)

ISBN 9780822361930 (pbk. : alk. paper)

ISBN 9780822374022 (e-book)

Subjects: LCSH: China-Economic conditions-2oth century. |

Economic Development-China. | China-Economic policy.

Classification: LCC HC427.95.G46 2016 (print) | LCC HC427.95

(ebook) | DDC 330.951-dc23 LC record available at http://lccn.loc.gov/2016004716

Cover art: Lu Hao, Duplicated Memories (2008). Installation.

Courtesy of the artist. Photograph by Yomi Braester. 